\title{
FAKTOR-FAKTOR YANG MEMPENGARUHI PENGGUNAAN MEDIA SOSIAL INSTAGRAM TERHADAP KEPUASAN PENGUSAHA WANITA
}

\section{Vanessya Blandina Dasmasela dan Hetty Karunia Tunjungsari}

\author{
Program Studi Manajemen, Fakultas Ekonomi dan Bisnis, Universitas Tarumanagara, Jakarta \\ Email:vanessya.115160473@stu.untar.ac.id, hetty@fe.untar.ac.id
}

\begin{abstract}
The purpose of this study was to determine and analyze the factors that influence the use of social media Instagram and its impact on the satisfaction of women entrepreneurs. This research was conducted by using judgment sampling method. Researchers distributed questionnaires to 200 women entrepreneurs. Data analysis using PLS SEM analysis. The results of the analysis conclude that Multi-channel has a significant effect on the use of social media among women entrepreneurs in West Jakarta. Trust has a significant effect on the use of social media among women entrepreneurs in West Jakarta. Ease has no significant effect on the use of social media among women entrepreneurs in West Jakarta. Accessibility has a significant effect on the use of social media among women entrepreneurs in West Jakarta. Security has a significant effect on the use of social media among female entrepreneurs in West Jakarta. Benefits have a significant effect on the use of social media among women entrepreneurs in West Jakarta. The use of social media has a significant effect on the satisfaction of women entrepreneurs in West Jakarta. The use of social media is able to mediate the effect of multi-channel on the satisfaction of entrepreneurs in West Jakarta. The use of social media is able to mediate the effect of trust on entrepreneur satisfaction in West Jakarta. The use of social media is not able to mediate the effect of convenience on the satisfaction of entrepreneurs in West Jakarta. The use of social media is able to mediate the effect of accessibility on entrepreneur satisfaction in West Jakarta. The use of social media is able to mediate the effect of security on the satisfaction of entrepreneurs in West Jakarta. The use of social media is able to mediate the effect of benefits on entrepreneur satisfaction in West Jakarta
\end{abstract}

Keywords: Multi-channel, trust, ease to use, Accessibility, security

Abstrak: Tujuan penelitian ini adalah untuk mengetahui dan menganalisa faktor-faktor yang mempengaruhi penggunaan media sosial instagram dan dampaknya terhadap kepuasan pengusaha wanita. Penelitian ini dilakukan dengan metode judgement sampling. Peneliti menyebarkan kuesioner kepada 200 pengusaha wanita. Analsisi data menggunakan analisis SEM PLS. Hasil analisis menyimpulkan bahwa Multi-channel berpengaruh signifikan terhadap penggunaan media sosial di kalangan pengusaha wanita di Jakarta Barat. Kepercayaan berpengaruh signifikan terhadap penggunaan media sosial di kalangan pengusaha wanita di Jakarta Barat. Kemudahan tidak berpengaruh signifikan terhadap penggunaan media sosial di kalangan pengusaha wanita di Jakarta Barat. Aksesibility berpengaruh signifikan terhadap penggunaan media sosial di kalangan pengusaha wanita di Jakarta Barat. Keamanan berpengaruh signifikan terhadap penggunaan media sosial di kalangan pengusaha wanita di Jakarta Barat. Manfaat berpengaruh signifikan terhadap penggunaan media sosial di kalangan pengusaha wanita di Jakarta Barat. Penggunaan media sosial berpengaruh signifikan terhadap kepuasan pengusaha wanita di Jakarta Barat. Penggunaan media sosial mampu memediasi pengaruh multi-channel terhadap kepuasan pengusaha di Jakarta Barat. Penggunaan media sosial mampu memediasi pengaruh kepercayaan 
terhadap kepuasan pengusaha di Jakarta Barat. Penggunaan media sosial tidak mampu memediasi pengaruh kemudahan terhadap kepuasan pengusaha di Jakarta Barat. Penggunaan media sosial mampu memediasi pengaruh aksesibility terhadap kepuasan pengusaha di Jakarta Barat. Penggunaan media sosial mampu memediasi pengaruh keamanan terhadap kepuasan pengusaha di Jakarta Barat. Penggunaan media sosial mampu memediasi pengaruh manfaat terhadap kepuasan pengusaha di Jakarta Barat.

Kata Kunci: Multi-channel, kepercayaan, kemudahan, aksesibility, keamanan.

\section{PENDAHULUAN}

Di era baru ini terdapat peningkatan bagi wanita dalam berwirausaha, namun di era ini juga wirausaha yang di tekuni begitu sangat berbeda dengan sebelum abad 20. Karena pada abad ini wanita sama sekali tidak di anggap dalam industry bisnis, wanita hanya di anggap sebagai ibu rumah tangga. Sama halnya dengan pengusaha, kata pengusaha selalu di sandingkan oleh pria, kesengjangan ini terjadi di hampir seluruh dunia, termasuk Indonesia. Thébaud, Sarah (2010) mengatakan bahwa gender masih menjadi halangan bagi sebagian wanita untuk memulai sebuah usaha karena wanita masih diragukan kemampuannya untuk memiliki usaha sendiri. Isu gender masih selalu menjadi semua masalah yang di hadapi oleh wanita di berbagai belahan Negara. Namun wanita sudah berani mengambil resiko dengan membuat sebuah bisnis dengan membantuh meningkat perekonomian dalam rumah. Sekarang wanita tidak hanya menjadi penonton dalam dunia bisnis, wanita mampu untuk menjalani dan membangun sebuah bisnis.dengan demikian wanita sudah membantu meningkat perekonomian dalam Negara tersebut,wanita pada era ini sudah mampu bersaing dengan pria dalam dunia bisnis.

Menurut Slamet dan Tunjungsari (2019) tak dapat dipungkiri lagi bahwa kewirausahaan menentukan kemakmuran suatu bangsa. Sejumlah studi memperlihatkan bahwa suatu negara membutuhkan minimal lima persen dari jumlah penduduk, berprofesi sebagai wirausaha yang dapat menciptakan kemakmuran suatu bangsa. Wirausaha yang dimaksud adalah mereka yang menjalankan usaha dengan memberikan nilai tambah di dalam bisnis yang mereka jalankan. Mereka menawarkan inovasi yang merupakan solusi bagi masyarakat luas, dan bisnis mereka terus tumbuh sehingga dapat memberikan kontribusi dalam penyediaan lapangan kerja dan pembayaran pajak kepada negara

Dalam survey sebelumnya yang dilakukan oleh Global Entrepreneurship Monitor (GEM) dilaporkan bahwa satu per tiga dari orang-orang yang terlibat dalam kegiatan kewirausahaan adalah wanita. Hal ini mencerminkan peran aktif wanita dalam pengembangan ekonomi suatu bangsa (Raman, Anantharaman and Jayasingam, 2008). ASEAN rata-rata sudah lebih dari empat persen" Wanita merupakan sumber daya yang seringkali tidak diberdayakan dalam upaya meningkatkan kesejahteraan masyarakat. Sehingga banyak potensi wanita yang terabaikan, karena kesalahan paradigm mengenai peran wanita dalam perekonomian. Padahal potensi wanita dalam meningkatkan roda perekonomian sangat besar, termasuk peluang untuk menjadi wirausahawan, sebagai pilihan bagi wanita untuk berkontribusi dalam perekonomian untuk mengangkat kesejahteraan bagi dirinya, keluarganya, bahkan masyarakat.

Berdasarkan latar belakang yang sudah di uraikan di atas, penulis tertarik meneliti pentingnya media sosial dalam berwisarausaha Jakarta Barat dengan mengangkat topik penelitian yang berjudul "Faktor-Faktor Yang Mempengaruhi Penggunaan Media Sosial Dan Dampaknya Terhadap Kepuasan Pengusaha Wanita" 


\section{Model dan Hipotesis Penelitian}

Berdasarkan uraian hubungan antar variabel di atas, maka model penelitian yang digunakan dalam penelitian ini adalah sebagai berikut :

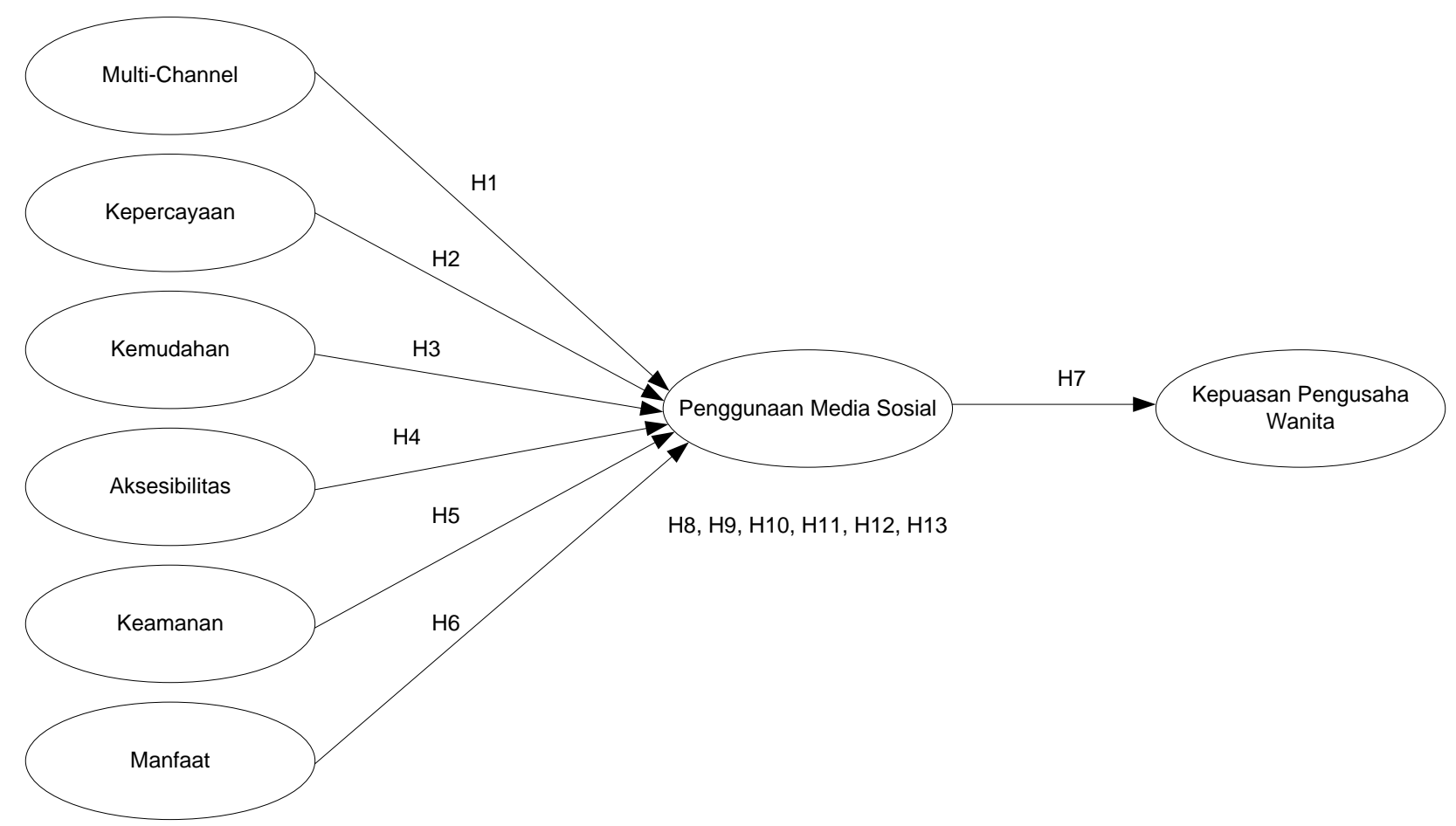

\section{Gambar 1.}

\section{Model Penelitian}

Hipotesis dalam penelitian ini adalah sebagai berikut:

H 1: Adanya pengaruh positif antara multi-channel dan penggunaan media social

$\mathrm{H} 2$ : Adanya pengaruh positif antara kepercayaan dan penggunaan media social

H3: Adanya pengaruh positif antara kemudahan penggunaan media sosial dan penggunaan media social

H 4: Adanya pengaruh positif antara aksesibilitas dan penggunaan media sosia

H 5: $\quad$ Adanya pengaruh positif antara keamanan dan penggunaan media social

H6: $\quad$ Adanya pengaruh positif antara manfaat dan penggunaan media social

H7: Adanya pengaruh positif antara penggunaan media sosial dan kepuasan pengusahawanita

H8: Penggunaan media sosial mampu memediasi pengaruh multi-channels terhadap kepuasan pengusahawanita

H9: Penggunaan media sosial mampu memediasi pengaruh kepercayaan terhadap kepuasan pengusahawanita

H10: Penggunaan media sosial mampu memediasi pengaruh kemudahan terhadap kepuasan pengusahawanita

H11: Penggunaan media sosial mampu memediasi pengaruh aksesibilitas terhadap kepuasan pengusahawanita

H12: Penggunaan media sosial mampu memediasi pengaruh keamanan terhadap kepuasan pengusahawanita

H 13: Penggunaan media sosial mampu memediasi pengaruh manfaat terhadap kepuasan pengusaha wanita 


\section{METODOLOGI}

Penelitian ini bertujuan untuk mengetahui pengaruh media sosial terhadap kepuasan wanita pengusaha. Subfaktor (misalnya multi-saluran, mudah digunakan, keamanan, aksesibilitas, kepercayaan dan manfaat) juga dimasukkan ke dalam studi untuk menentukan faktor utama yang mempengaruhi perilaku penggunaan media sosial perempuan pengusaha. Sebagai desain penelitian kuantitatif, penelitian deskriptif diterapkan untuk menggambarkan hubungan antar konstruksi.

Berdasarkan karakteristiknya, penelitian ini adalah penelitian deskriptif yaitu penelitian dengan cara mengumpulkan data dari sebuah sampel dengan tujuan untuk mengetahui karakteristik dari suatu populasi (Sekaran dan Bougie, 2016). Pendekatan yang digunakan dalam penelitian ini adalah pendekatan cross sectional. Menurut Sekaran dan Bougie (2016), pendekatan cross sectional merupakan suatu penelitian dimana informasi atau data dikumpulkan dari subyek penelitian yang digunakan hanya satu kali dalam satu periode waktu untuk menjawab rumusan masalah.

Menurut Aritonang (2007:95) populasi penelitian adalah "keseluruhan unsur yang menjadi subjek penelitian, sedangkan bagian dari populasi tersebut dinamakan sampel". Dalam penelitian ini yang menjadi populasi adalah seluruh pengusaha wanita yang berada di wilayah Jakarta Barat. Dalam penelitianini, pengambilan sampel dilakukan secara tidak acak dengan menggunakan teknik judgement sampling. Judgement sampling adalah pengambilan sampel berdasarkan pertimbangan tertentu yang melibatkan pemilihan subjek yang berada ditempat yang paling menguntungkan atau dalam posisi terbaik untuk memberikan informasi yang diperlukan Sekaran dan Bougie (2016). Jumlah responden yang digunakan adalah 200 orang yang merupakan pemilik Usaha yang bergerak dalam bidang jual beli produk dan/atau jasa.

Berikut akan dijelaskan mengenai jenis variabel, indikator variabel, skala, dan acuan yang digunakan dalam membuat operasional variabel. Pada penelitian ini, green brand affect (X) menjadi variabel independen, kemudian green purchase intentions (Y) sebagai dependen, lalu green brand associations dan green brand attitude $(\mathrm{M})$ sebagai mediasi.

\section{Operasionalisasi Variabel}

Menurut Sekaran dan Bougie (2016) definisi operasional adalah definisi dari suatu konstruk secara terukur dengan cara mengurangi tingkat abstraksi melalui penggambaran dimensi dan elemen. Variabel penelitian dalam penelitian ini adalahMulti-Channel, Kepercayaan, Kemudahan, Aksesibilitas, Keamanan, Persepsi manfaat, Penggunaan media, Kepuasan.

Tabel 1. Indikator Pengukuran Variabel

\begin{tabular}{ccc}
\hline Variabel & Item & Sumber \\
\hline Multi-Channel & 3 items & Merza (2019) \\
\hline Kepercayaan & 4 items & Merza (2019) \\
\hline Kemudahan & 3 items & Merza (2019) \\
\hline Aksesibility & 4 items & Merza (2019) \\
\hline Keamanan & 4 items & Merza (2019) \\
\hline Persepsi manfaat & 3 items & Merza (2019) \\
\hline Penggunaan Media Sosial & 5 items & Merza (2019) \\
\hline Kepuasan & 3 items &
\end{tabular}


Instrumen merupakan alat yang digunakan oleh peneliti untuk mengumpulkan data dan informasi yang dibutuhkan guna menyelesaikan permasalahan yang ada. Intrumen yang peneliti gunakan dalam pengumpulan data adalah kuesioner. Penyebaran kuesioner dilakukan secara online melalui social media seperti WhatsApp, Instagram dan Line kepada calon responden yang tersebar di seluruh Jakarta. Hal ini dilakukan mengingat waktu dan biaya yang minim.

Skala yang digunakan pada penelitian ini adalah skala ordinal dengan bentuk skala likert dimana terdapat 1-6 skala dengan keterangan:

Keterangan :

1 = Sangat Tidak Setuju (STS)

$2=$ Tidak Setuju $(\mathrm{TS})$

$3=$ Kurang Setuju (KS)

$4=$ Cukup Setuju (CS)

$5=$ Setuju $(S)$

$6=$ Sangat Setuju (SS)

\section{Analisis Validitas Dan Reliabilitas}

\section{Analisis Validitas}

Uji validitas digunakan agar dapat mengukur sah atau valid tidaknya suatu kuesioner. Suatu kuesioner dikatakan valid jika pertanyaan di dalam kuesioner mampu untuk mengungkapkan sesuatu yang akan diukur oleh kuesioner tersebut (Ghozali, 2014:124). Convergent Validity

Menurut Ghozali (2014:125) Convergent validity digunakan untuk mengukur dalam menentukan apakah setiap indikator yang diestimasi secara valid mengukur dimensi dari konsep yang diukur. Ukuran refleksif individu dikatakan tinggi jika berkorelasi lebih dari 0.70 dengan konstruk yang ingin diukur. Berikut adalah output Smartpls untuk menguji validitas:

Tabel 2

Convergent Validity

\begin{tabular}{|l|c|c|c|c|l|l|l|l|}
\hline & $\begin{array}{c}\text { Aksesi } \\
\text { bility }\end{array}$ & $\begin{array}{c}\text { Keam } \\
\text { anan }\end{array}$ & $\begin{array}{c}\text { Kemu } \\
\text { dahan }\end{array}$ & $\begin{array}{c}\text { Keper } \\
\text { cayaan }\end{array}$ & Kepuasan & Manfaat & $\begin{array}{c}\text { Multi- } \\
\text { Channel }\end{array}$ & Penggunaan \\
\hline Aks1 & 0.930 & & & & & & & \\
\hline Aks2 & 0.886 & & & & & & & \\
\hline Aks3 & 0.917 & & & & & & & \\
\hline Aks4 & 0.896 & & & & & & & \\
\hline Kea1 & & 0.896 & & & & & & \\
\hline Kea2 & & 0.926 & & & & & & \\
\hline Kea3 & & 0.905 & & & & & & \\
\hline Kea4 & & 0.902 & & & & & & \\
\hline Kem1 & & & 0.903 & & & & & \\
\hline Kem2 & & & 0.946 & & & & & \\
\hline Kem3 & & & 0.898 & & & & & \\
\hline Kep1 & & & & 0.889 & & & & \\
\hline Kep2 & & & & 0.826 & & & & \\
\hline Kep3 & & & & 0.837 & & & & \\
\hline Kep4 & & & & 0.904 & & & & \\
\hline
\end{tabular}




\begin{tabular}{|r|l|l|l|l|l|l|l|}
\hline Kep5 & & & 0.894 & & & & \\
\hline Kp1 & & & & 0.904 & & & \\
\hline Kp2 & & & & 0.926 & & & \\
\hline Kp3 & & & & 0.970 & & & \\
\hline MC1 & & & & & & 0.907 & \\
\hline MC2 & & & & & & 0.920 & \\
\hline MC3 & & & & & & 0.919 & \\
\hline Man1 & & & & & 0.933 & & \\
\hline Man2 & & & & & 0.961 & & \\
\hline Man3 & & & & & 0.942 & & \\
\hline Peng1 & & & & & & & 0.872 \\
\hline Peng2 & & & & & & & 0.892 \\
\hline Peng3 & & & & & & & 0.895 \\
\hline Peng4 & & & & & & & 0.876 \\
\hline Peng5 & & & & & & & 0.861 \\
\hline
\end{tabular}

Sumber: Olahan data smartPLS 3.00

Berdasarkan Tabel di atas seluruh butir pernyataan memiliki loading factor lebih dari 0,7 sehingga seluruh butir pernyataan valid secara konvergen (convergent validity). Dengan nilai tertinggi dalam indikator Kp3 yaitu 0,970 dan nilai terendah terdapat dalam indikator Kep2, yaitu 0.826. Sehingga dapat disimpulkan bahwa semua indikator yang digunakan dalam penelitian ini memenuhi syarat. Berikut gambar diagram loading factors setiap indicator.

Tabel 3

Avarage Variance Extracted

\begin{tabular}{|l|c|}
\hline & $\begin{array}{c}\text { Avarage Variance } \\
\text { Extracted }\end{array}$ \\
\hline Multi-Channel & 0,837 \\
\hline Kepercayaan & 0,758 \\
\hline Kemudahan & 0,839 \\
\hline Aksesibility & 0,823 \\
\hline Keamanan & 0,823 \\
\hline Manfaat & 0,894 \\
\hline Penggunaan Media Sosial & 0,773 \\
\hline Kepuasan & 0,871 \\
\hline
\end{tabular}

Sumber: Olahan data smartPLS 3.00

Berdasarkan hasil dari Average Variance Extracted (AVE) dalam tabel di atas menunjukkan bahwa nilai Average Variance Extracted (AVE) dalam penelitian ini memiliki hasil yang bagus dimana dalam setiap nilai indikator berada diatas 0,5 . Itu bearti nilai Average Variance Extracted (AVE) memenuhi kriteria. 


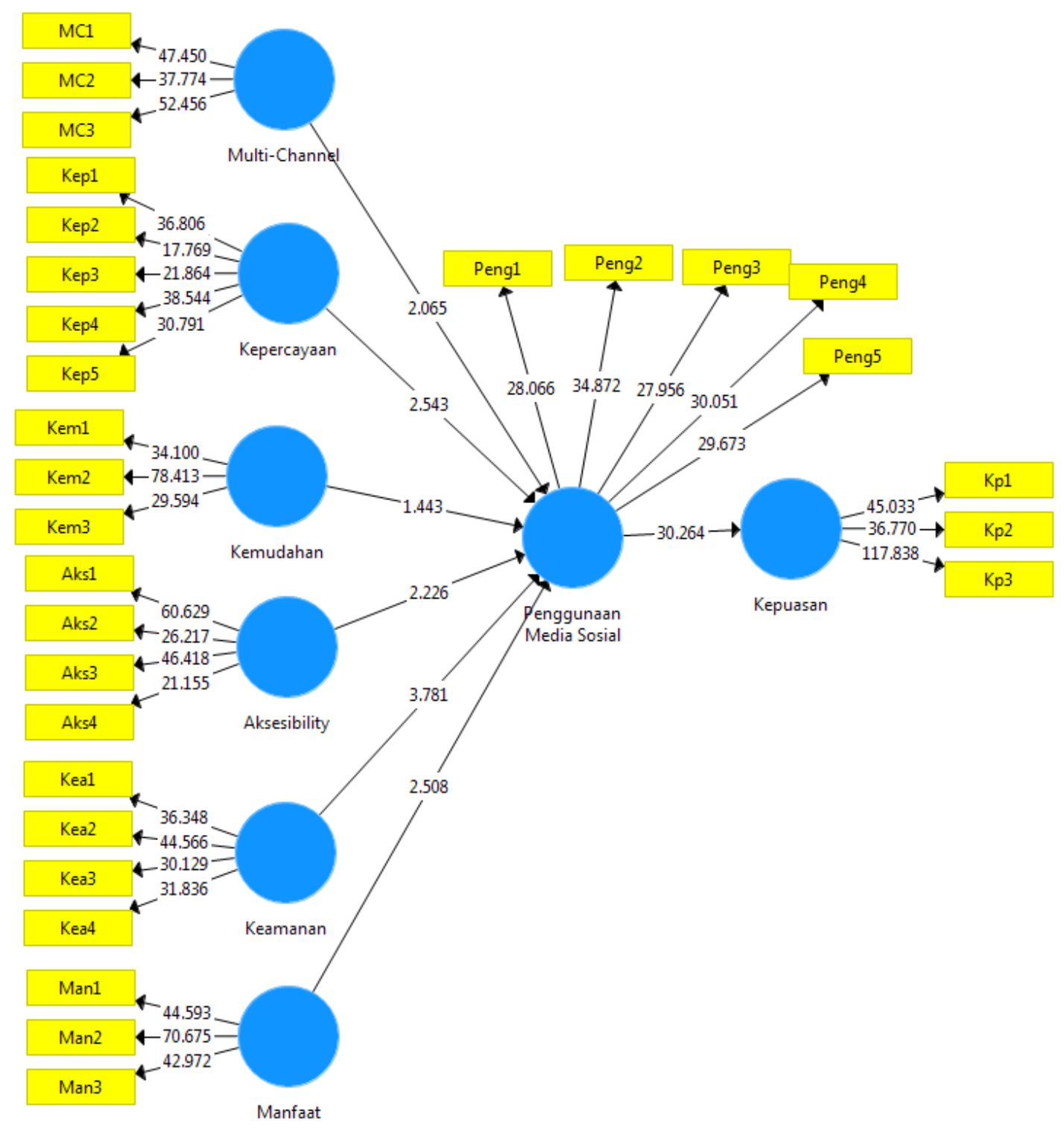

Sumber: data olahan SmartPLS 3.00

\section{Gambar 2. Diagram Loading Factors}

Berdasarkan Gambar 2 seluruh butir pernyataan memiliki loading factor lebih dari 0,7 sehingga seluruh butir pernyataan valid secara konvergen (convergent validity).

\section{Discriminant Validity}

Menurut Ghozali (2014:127) Discriminant validity dilakukan di dalam dua tahap, ialah dengan cara melihat nilai cross loading factor serta membandingkan akar AVE (Average Variance Extracted) dengan korelasi diantar konstruk/variabel laten. Cross loading factor agar dapat mengetahui apakah variabel laten mempunyai diskriminan yang memadai yaitu dengan cara membandingkan korelasi indikator terhadap variabel latennya harus lebih besar dibandingkan korelasi di antara variabel dengan variabel laten yang lain. Kalau korelasi variabel dengan variabel latennya memiliki nilai lebih tinggi terhadap korelasi variabel tersebut terhadap variabel laten lain, maka dikatakan variabel laten itu memiliki validitas diskriminan yang tinggi. Berikut 
adalah hasil discriminant validity:

Tabel 5

Hasil Uji Cross Loading

\begin{tabular}{|c|c|c|c|c|c|c|c|c|}
\hline & $\begin{array}{c}\text { Aksesi } \\
\text { bility }\end{array}$ & $\begin{array}{c}\text { Keam } \\
\text { anan }\end{array}$ & $\begin{array}{l}\text { Kemu } \\
\text { dahan }\end{array}$ & $\begin{array}{l}\text { Keper } \\
\text { cayaan }\end{array}$ & Kepuasan & Manfaat & $\begin{array}{c}\text { Multi- } \\
\text { Channel }\end{array}$ & Penggunaan \\
\hline Aks1 & 0.930 & 0.769 & 0.842 & 0.779 & 0.724 & 0.770 & 0.679 & 0.785 \\
\hline Aks2 & 0.886 & 0.804 & 0.813 & 0.746 & 0.703 & 0.772 & 0.692 & 0.793 \\
\hline Aks3 & 0.917 & 0.767 & 0.830 & 0.816 & 0.755 & 0.786 & 0.759 & 0.825 \\
\hline Aks4 & 0.896 & 0.779 & 0.757 & 0.738 & 0.771 & 0.761 & 0.612 & 0.782 \\
\hline Kea1 & 0.851 & 0.896 & 0.779 & 0.775 & 0.792 & 0.778 & 0.689 & 0.837 \\
\hline Kea2 & 0.810 & 0.926 & 0.814 & 0.772 & 0.718 & 0.793 & 0.687 & 0.843 \\
\hline Kea3 & 0.770 & 0.905 & 0.787 & 0.727 & 0.675 & 0.792 & 0.651 & 0.785 \\
\hline Kea4 & 0.689 & 0.902 & 0.713 & 0.739 & 0.657 & 0.781 & 0.712 & 0.839 \\
\hline Kem1 & 0.780 & 0.786 & 0.903 & 0.771 & 0.652 & 0.727 & 0.688 & 0.782 \\
\hline Kem2 & 0.847 & 0.771 & 0.946 & 0.850 & 0.731 & 0.724 & 0.769 & 0.779 \\
\hline Kem3 & 0.830 & 0.784 & 0.898 & 0.782 & 0.645 & 0.738 & 0.704 & 0.744 \\
\hline Kep1 & 0.737 & 0.716 & 0.757 & 0.889 & 0.684 & 0.740 & 0.886 & 0.786 \\
\hline Kep2 & 0.591 & 0.639 & 0.663 & 0.826 & 0.573 & 0.597 & 0.688 & 0.739 \\
\hline Kep3 & 0.782 & 0.701 & 0.763 & 0.837 & 0.768 & 0.685 & 0.804 & 0.788 \\
\hline Kep4 & 0.800 & 0.469 & 0.802 & 0.904 & 0.691 & 0.763 & 0.763 & 0.781 \\
\hline Kep5 & 0.776 & 0.784 & 0.814 & 0.894 & 0.712 & 0.745 & 0.759 & 0.786 \\
\hline $\mathrm{Kp} 1$ & 0.853 & 0.801 & 0.791 & 0.822 & 0.904 & 0.768 & 0.731 & 0.852 \\
\hline Kp2 & 0.680 & 0.658 & 0.601 & 0.657 & 0.926 & 0.623 & 0.639 & 0.730 \\
\hline Kp3 & 0.732 & 0.722 & 0.660 & 0.720 & 0.970 & 0.684 & 0.700 & 0.799 \\
\hline MC1 & 0.639 & 0.618 & 0.683 & 0.812 & 0.650 & 0.661 & 0.907 & 0.737 \\
\hline MC2 & 0.707 & 0.723 & 0.745 & 0.785 & 0.701 & 0.713 & 0.920 & 0.782 \\
\hline MC3 & 0.728 & 0.729 & 0.729 & 0.866 & 0.686 & 0.751 & 0.919 & 0.788 \\
\hline Man1 & 0.817 & 0.782 & 0.701 & 0.765 & 0.716 & $\mathbf{0 . 9 3 3}$ & 0.712 & 0.845 \\
\hline Man2 & 0.796 & 0.821 & 0.755 & 0.764 & 0.728 & 0.961 & 0.739 & 0.826 \\
\hline Man3 & 0.802 & 0.853 & 0.803 & 0.776 & 0.670 & 0.942 & 0.748 & 0.844 \\
\hline Peng1 & 0.766 & 0.795 & 0.761 & 0.738 & 0.688 & 0.794 & 0.712 & 0.872 \\
\hline Peng2 & 0.783 & 0.832 & 0.681 & 0.723 & 0.733 & 0.797 & 0.678 & 0.892 \\
\hline Peng3 & 0.772 & 0.824 & 0.742 & 0.787 & 0.717 & 0.832 & 0.761 & 0.895 \\
\hline Peng4 & 0.722 & 0.773 & 0.724 & 0.832 & 0.763 & 0.743 & 0.768 & 0.876 \\
\hline Peng5 & 0.812 & 0.781 & 0.778 & 0.836 & 0.846 & 0.734 & 0.771 & 0.861 \\
\hline
\end{tabular}

Sumber: Olahan data smartPLS 3.00

Suatu indikator dikatakan valid jika memiliki loading factor lebih tinggi kepada konstruk yang dituju dibandingkan loading factor kepada konstruk lain. Hasil pada table 5 di atas memperlihatkan bahwa konstruk laten memprediksi indikator pada blok mereka lebih baik di 
bandingkan dengan indikator di blok yang lain.

Hasil dari semua uji validitas didalam outer model dengan menilai convergent validity, discriminant validity, dan nilai $A V E$ memperlihatkan bahwa semua indikator telah valid

\section{Analisis Reliabilitas}

Instrumen yang reliabel ialah instrumen yang dapat memberikan hasil pengukuran yang relatif sama bila instrumen tersebut digunakan untuk dapat mengukur variabel yang sama pada dua atau lebih waktu yang berbeda pada keadaan yang kurang lebih sama (Aritonang, 2007:136). Menurut Malhotra (2012:215) reliabilitas ialah instrumen yang dapat memberikan hasil pengukuran yang (relatif) sama bila instrumen itu digunakan terhadap pengukuran variabel yang sama pada dua atau lebih waktu yang berbeda di dalam keadaan yang kurang sama. Pengujian realibilitas instrumen menggunakan nilai koefisien composite reability dan Cronbach's Alpha. Suatu instrumen dinyatakan reliable bila nilai Cronbach's Alpha> 0,7. Uji reabilitas di dalam penelitian ini menggunakan Composite Reability dan Cronbach's Alpha.

\section{Composite Reliability}

Uji reliabilitas dilaksanakan dengan melihat nilai composite reliability. Hasil composite reliability dikatakan reliable jika memiliki nilai diatas 0.7 . Berikut ialah nilai composite reliability pada tabel 3.6

Tabel 6

Composite Reliability

\begin{tabular}{|l|c|c|}
\hline & $\begin{array}{c}\text { Composite } \\
\text { Reliability }\end{array}$ & $\begin{array}{c}\text { Cronbach's } \\
\text { Alpha }\end{array}$ \\
\hline Multi-Channel & 0,939 & 0,903 \\
\hline Kepercayaan & 0,940 & 0,920 \\
\hline Kemudahan & 0,940 & 0,904 \\
\hline Aksesibility & 0,949 & 0,928 \\
\hline Keamanan & 0,949 & 0,928 \\
\hline Manfaat & 0,962 & 0,941 \\
\hline Penggunaan Media Sosial & 0,945 & 0,927 \\
\hline Kepuasan & 0,953 & 0,926 \\
\hline
\end{tabular}

Sumber: Olahan data smartPLS 3.00

Tabel 6 memperlihatkan bahwa nilai composite reliability dan conbach alpha ialah semua konstruk memiliki nilai diatas 0.7 yang memperlihatkan bahwa semua konstruk pada model yang diestimasi memenuhi kriteria composite reliability.

\section{DISKUSI}

Hipotesis yang pertama menunjukkan bahwa variabel multi-channel berpengaruh terhadap penggunaan media sosial, maka dapat disimpulkan bahwa $\mathrm{H}_{1}$ tidak ditolak. Sehingga dapat dikatakan bahwa variabel multi-channel berpengaruh signifikan terhadap penggunaan media sosial dikalangan pengusaha wanita di Jakarta Barat. Hasil ini sesuai dengan Merza (2019), Aryanto (2010) dan Azman (2018) yang menyatakan bahwa multi-channel berpengaruh terhadap penggunaan media sosial. Pengusaha dapat menggunakan media sosial untuk melakukan pemasaran multisaluran. Dengan banyaknya saluran yang didapat di dalam media sosial seorang pengusaha dapat melakukan pemasaran yang memiliki cakupan yang lebih luas.

Kemudian untuk hipotesis kedua variabel keercayaan berpengaruh signifikan terhadap 
penggunaan media sosial di kalangan pengusaha di Jakarta Barat. Hasil ini sesuai dengan penelitian Wibowo, dkk (2015), Merza (2019) Yogananda dan Dirgantara (2017) dan Wardhana (2016) juga menyatakan bahwa kepercayaan berpengaruh terhadap seseorang menggunakan media sosial. Instrumen media sosial merupakan sebuah produk yang cukup baru di masyarakat, oleh karena itu kepercayaan menjadi faktor yang sangat penting dalam penggunaannya. Pihak perusahaan harus mengutamakan kepuasan pelanggan agar dapat membuat masyarakat percaya dengan media sosial.

Kemudian untuk hipotesis ketujuh variabel penggunaan media sosial berpengaruh signifikan terhadap kepuasan pengusaha di Jakarta Barat. Hasil ini sesuai dengan penelitian Merza (2019), Putri dan Mei Ie (2020), Lathifah dan Lubis (2018), Sanggabuwana dan Andrini (2017) yang menyimpulkan bahwa media sosial berpengaruh terhadap kepuasan pengusaha.

Hasil pengujian mediasi variabel multi-channel terhadap kepuasan melalui variabel penggunaan media sosial diketahui bahwa variabel penggunaan media sosial mampu memediasi pengaruh multi-channel terhadap kepuasan pengusaha di Jakarta Barat. Hasil pengujian mediasi variabel kepercayaan terhadap kepuasan melalui variabel penggunaan media sosial diketahui bahwa variabel penggunaan media sosial mampu memediasi pengaruh kepercayaan terhadap kepuasan pengusaha di Jakarta Barat. Hasil pengujian mediasi variabel kemudahan terhadap kepuasan melalui variabel penggunaan media sosial diketahui bahwa variabel penggunaan media sosial tidak mampu memediasi pengaruh kemudahan terhadap kepuasan pengusaha di Jakarta Barat. Hasil pengujian mediasi variabel aksesibility terhadap kepuasan melalui variabel penggunaan media sosial diketahui bahwa variabel penggunaan media sosial mampu memediasi pengaruh aksesibility terhadap kepuasan pengusaha di Jakarta Barat. Hasil pengujian mediasi variabel keamanan terhadap kepuasan melalui variabel penggunaan media sosial diketahui bahwa variabel penggunaan media sosial mampu memediasi pengaruh keamanan terhadap kepuasan pengusaha di Jakarta Barat. Hasil pengujian mediasi variabel manfaat terhadap kepuasan melalui variabel penggunaan media sosial diketahui bahwa variabel penggunaan media sosial mampu memediasi pengaruh manfaat terhadap kepuasan pengusaha di Jakarta Barat.

\section{KESIMPULAN}

Berdasarkan analisis dan pembahasan, maka dapat diambil beberapa kesimpulan sebagai berikut:Multi-channel berpengaruh signifikan terhadap penggunaan media sosial di kalangan pengusaha wanita di Jakarta Barat. Kepercayaan berpengaruh signifikan terhadap penggunaan media sosial di kalangan pengusaha wanita di Jakarta Barat. Kemudahan tidak berpengaruh signifikan terhadap penggunaan media sosial di kalangan pengusaha wanita di Jakarta Barat. Aksesibility berpengaruh signifikan terhadap penggunaan media sosial di kalangan pengusaha wanita di Jakarta Barat. Keamanan berpengaruh signifikan terhadap penggunaan media sosial di kalangan pengusaha wanita di Jakarta Barat. Manfaat berpengaruh signifikan terhadap penggunaan media sosial di kalangan pengusaha wanita di Jakarta Barat. Penggunaan media sosial berpengaruh signifikan terhadap kepuasan pengusaha wanita di Jakarta Barat. Penggunaan media sosial mampu memediasi pengaruh multi-channel terhadap kepuasan pengusaha di Jakarta Barat. Penggunaan media sosial mampu memediasi pengaruh kepercayaan terhadap kepuasan pengusaha di Jakarta Barat. Penggunaan media sosial tidak mampu memediasi pengaruh kemudahan terhadap kepuasan pengusaha di Jakarta Barat. Penggunaan media sosial mampu memediasi pengaruh aksesibility terhadap kepuasan pengusaha di Jakarta Barat. Penggunaan media sosial mampu memediasi pengaruh keamanan terhadap kepuasan pengusaha di Jakarta Barat. Penggunaan media sosial mampu memediasi pengaruh manfaat terhadap kepuasan 
pengusaha di Jakarta Barat.

\section{DAFTAR PUSTAKA}

Aryanto. (2010). Pengolahan Database MySQL. Yogyakarta: Budi Utama

Aritonang,R.Lerbin. (2007). Teori dan Praktik Riset Pemasaran Bogor. Ghalia Indonesia

Azman (2018) Penggunaan Media Massa dan Media Sosial di Kalangan Mahasiswa Komunikasi. Jurnal Peurawi. 1 (1), 1-13

Ghozali, Imam. (2014). Structural Equation Modeling, Metode Alternatif dengan Partial Least Square (PLS). Edisi 4. Semarang : Badan Penerbit Universitas Diponegoro

Lathifah, Zahrah dan Djuara P. Lubis (2016) Hubungan Penggunaan Media Sosial Dengan Perkembangan Usaha Kecil Dan Menengah Kuliner Wilayah Solo Raya. Jurnal Komunikasi Pembangunan. 16 (1 ), 75-88

Merza, Ziauddin (2019) The Role And Importance Of Social Media On Women Entrepreneurship.Development Economics: Women, Gender, \& Human Development eJournal. 1(4), 1-24

Malhotra, Naresh K. (2012). Riset Pemasaran Pendekatan Terapan. Jakarta: Index.

Putri, Yohani Dwi dan Mei Ie (2020) Pengaruh Orientasi Kewirausahaan, Lingkungan dan Media Sosial terhadap Kinerja Usaha UMKM di Jakarta.Jurnal Manajerial dan Kewirausahaan. 2 (4), 1106-111

Raman, Kavitha; Anantharaman, R.N. and Sharmila Jayasingam (2008). Motivational Factors Affecting Entrepreneurial Decision: A Comparison between Malaysian Women Entrepreneurs and Women Non Entrepreneurs. Communications of the IBIMA. 2 (1), 8589

Sanggabuwana, Danang dan Susi Andrini (2017) Dampak Media Sosial Terhadap Usaha Kecil Dan Menengah (Ukm) Sentra Industri Keramik Plered, Kabupaten Purwakarta. Jurnal Komunikasi. 2 (2), 172-181

Sekaran, Uma dan Bougie, Roger. (2016). Research Methods For Business: A Skill Building Approach, 7th Edition. New Jersey: Wiley

Slamet, F., \& Tunjungsari, H. K. (2019). Pengembangan kewirausahaan untuk siswa SMA Saint John's Catholic School Meruya melalui peningkatan pemahaman identifikasi ide bisnis. Jurnal Bakti Masyarakat Indonesia, 22-28.

Thebaud, Sarah. (2010).Gender and Entrepreneurship as a Career Choice: Do Self- assessments of Ability Matter?Social Psychology Quarterly. 73(3), 1-15

Wardhana, Onny Herlambang Putra (2016) Pengaruh Persepsi Kemudahan, Persepsi Kegunaan, Persepsi Nilai, Pengaruh Sosial, Persepsi Risiko, dan Kepercayaan Terhadap Minat Menggunakan E-commerce.Jurnal Ilmia Mahasiswa Fakultas Ekonomi dan Bisnis. 4 (2), $1-28$

Wibowo, Setyo Ferry, Dede Rosmauli dan Usep Suhud (2015). Pengaruh Persepsi Manfaat, Persepsi Kemudahan, Fitur Layanan, Dan Kepercayaan Terhadap Minat Menggunakan EMoney Card (Studi Pada Pengguna Jasa Commuterline Dijakarta).Jurnal Riset Manajemen Sains Indonesia . 6 (1),441-456

Yogananda, A. S., dan I. M. B. Dirgantara, (2017) Pengaruh Persepsi Manfaat, Persepsi Kemudahan Penggunaan, Kepercayaan Dan Persepsi Risiko Terhadap Minat Untuk Menggunakan Instrumen Uang Elektronik. Diponegoro Journal Of Management. 6 (4), 116-122 